\title{
RNA Model of IPM Motor Using Variable Magnetomotive Forces and Variable Reluctances
}

\author{
K. Suzuki, K. Nakamura, and O. Ichinokura \\ Graduate School of Engineering, Tohoku University, 6-6-05 Aoba, Aramaki, Aoba-ku, Sendai 980-8579, Japan
}

\begin{abstract}
Interior permanent magnet (IPM) motors have large amounts of torque and are much more efficient than other motors since they can utilize both magnetic torque and reluctance torque together. However, the current vector needs to be controlled to utilize both torques effectively. Hence, it is necessary to design and analyze motor drive circuits in addition to motor structures. We propose a method of calculating the characteristics of an IPM motor based on reluctance network analysis (RNA). The proposed RNA model of the IPM motor consists of multiple nonlinear reluctances and magnetomotive forces, which periodically change with the rotor position so that the rotary motion of the rotor can be simulated. The RNA model can easily be coupled with an electric circuit and mechanical system. Therefore, it is suitable for designing and analyzing the IPM motor-drive system. The validity of the proposed method is proved by comparing its results with those obtained from the finite element method (FEM).
\end{abstract}

Key words: interior permanent magnet (IPM) motor, reluctance network analysis (RNA), iron loss

\section{可変起磁力と可変磁気抵抗を用いた IPM モータの RNA モデル \\ 鈴木 邦彰・中村 健二・一ノ倉 理 \\ 東北大学大学院工学研究科, 仙台市青葉区荒巻字青葉 6-6-05 ( 980-8579)}

\section{1. はじめに}

地球温暖化や省資源・省エネルギーに対する関心は全世 界で急速に高まっており，家電，民生，運輸などの幅広い 分野において, 小型, 高出力, 高効率な永久磁石モータの 需要が急増している. 同時に, モータのさらなる高性能化 が強く要求されている.

埋込磁石 (IPM : Interior Permanent Magnet) モータ は, マグネットトルクに加えて, 磁気的突極性に起因する リラクタンストルクも併用できるため, 高トルク, 高効率 であるが，その性能はモータ構造のみならず，制御手法に も強く依存する，そのため，IPM モータの高性能化のため には，制御系も含めた解析・設計が必要不可欠である。

有限要素法（FEM : Finite Element Method）は，電気 機器の形状や材料特性を考慮した詳細な磁場解析が可能で あり，計算精度も高いため，モータ構造の最適設計に適す る. 一方, 解析には十分な計算機容量と計算時間が必要で あり, また制御系まで含めた解析は必ずしも容易ではない.

これに対して, 筆者らは解析対象である電気機器を複数 の要素に分割し，分割した各々の要素を磁気抵抗に置き換 えることで, 機器全体を 1 つの磁気抵抗回路網としてモデ ル化して解析する，いわゆるリラクタンスネットワーク解 析 (RNA : Reluctance Network Analysis) によるモータ の解析・設計について研究を進めている 1)-4)。本手法は, (1)機器の形状や非線形磁気特性を考慮したシンプルな解析 モデルが構築でき, 簡便な計算で機器性能を精度良く見積 もることができる, (2)電気系や運動系, 制御系, 熱系など との連成解析も容易であり，計算には SPICE などの汎用 の回路シミュレータを利用できるなどの特長を有するた め, モータドライブシステムの解析・設計に適した手法で あると考えられる。
先に筆者らは，ギャップの磁気抵抗を回転子位置角に応 じて変化する可変の磁気抵抗とし, 固定子と回転子の磁気 回路の接続を，この可変磁気抵抗を用いて切り換えていく ことで，回転子の回転運動を表現した IPM モータの RNA モデルについて検討を行った ${ }^{5)}$ ，その結果，モータトルク については精度良く算定できることを明らかにしたが，一 方で誘起電圧波形には，磁気抵抗の接続の切り換えに起因 するスパイク状のノイズが重畳する問題があった.

そこで本稿では，ギャップ磁気抵抗では無く，永久磁石 の起磁力と回転子の磁気抵抗を回転子位置角の関数で表す ことで, 回転子の回転運動を模擬する新しい IPM モータの RNA モデルを構築し，基礎特性ならびに鉄損の算定を行っ たので報告する.

\section{IPM モータの RNA モデルの導出とトルクの計算手法}

\subsection{2 次元 RNA モデルの導出}

Fig. 1 に，考察に用いた IPM モータの諸元を示す. 3 相 12 スロット 8 極のモータであり, 巻線は固定子極に集中巻 されている．磁石材料は Nd-Fe-B であり，保磁力は 900 $\mathrm{kA} / \mathrm{m}$ ，リコイル比透磁率は 1.061 である。また，磁石は回 転子表面から $0.5 \mathrm{~mm}$ の位置に埋め込まれている.

以下では，IPM モータの 2 次元 RNA モデルの導出方法 について述べる.まず, Fig. 1 の IPM モータを形状ならび に磁束の流れを勘案して, 複数の要素に分割する. 次いで, 分割した要素を, Fig. 2 に示すような, 径方向と周方向の 4 つの磁気抵抗で構成される単位磁気回路に置き換える。こ れらの磁気抵抗をつなぎ合わせることで，2 次元の磁気抵 抗回路網が構築される.

Fig. 3 に, 導出された RNA モデルの一部を示す. 固定子 は 1 極あたり径方向に 4 分割, 周方向にはヨーク側は 2 分 割, 回転子に近い極側は磁束分布が複雑になるため, 5 分 
割している. ギャップと回転子の周方向の分割数は，2 度 ずつ等間隔で分割しており, 1 周で 180 分割となる.また, 回転子の径方向には 3 分割されている.

Fig. 3 の回路中の磁気抵抗および起磁力の導出方法につ いて述べる. まず，Fig. 4 に示す鉄心材料の $B-H$ 曲線を， 次の非線形関数で近似する.

$$
H=\alpha_{1} B+\alpha_{m} B^{m}
$$

ここで， $\alpha_{1}$ および $\alpha_{m}$ は係数である. 次数 $m$ は 3 以上の奇 数であり, 磁気特性の非線形性の強さに応じて適切に選択 する必要があるが，ここでは $m=13$ とした。

磁路の断面積を $S$, 長さを $l$ とすれば, 起磁力 $f_{m}$, 磁気抵 抗 $R_{m}$, および磁束 $\phi$ 関係は，(1)式から次式のように求め ることができる.

$$
\begin{aligned}
f_{m} & =R_{m} \phi \\
& =\left(\frac{\alpha_{1} l}{S}+\frac{\alpha_{13} l}{S^{13}} \phi^{12}\right) \phi
\end{aligned}
$$

上式の括弧内が非線形磁気抵抗に相当する.

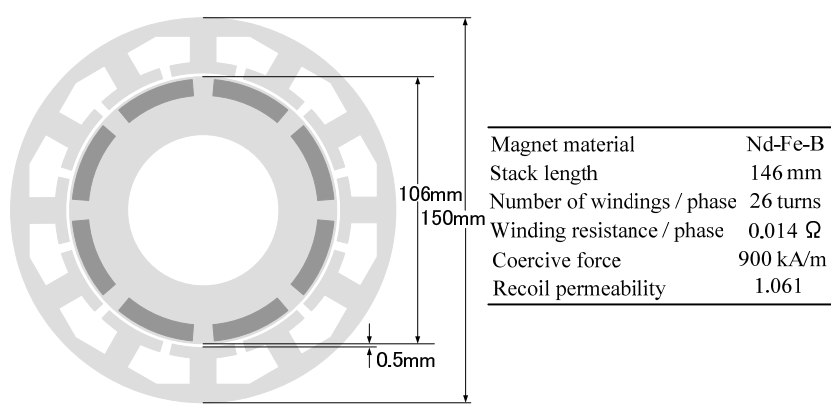

Fig. 1 Specifications of IPM motor.

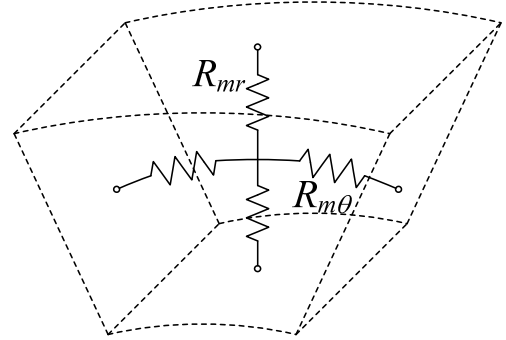

Fig. 2 Unit magnetic circuit of RNA.

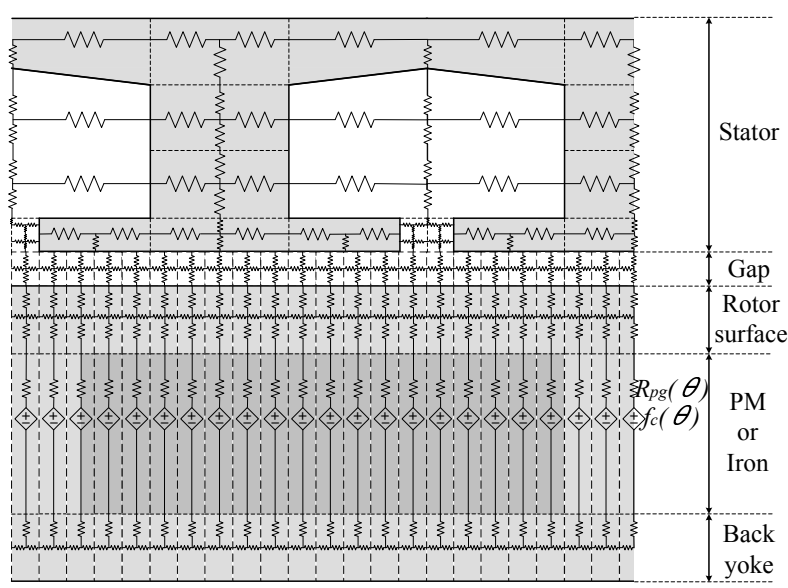

Fig. 3 Expanded view of RNA model.

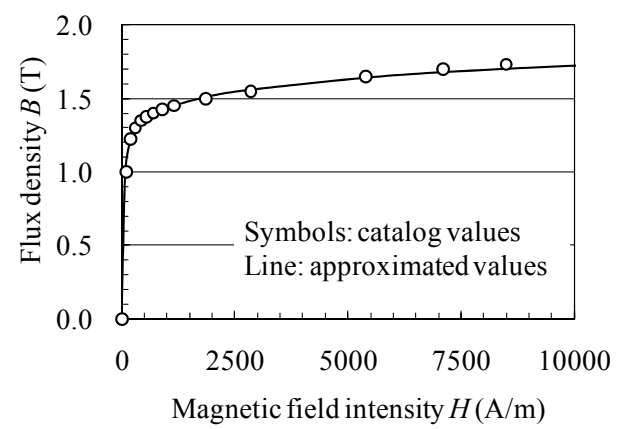

Fig. $4 \quad B-H$ curve of core material and its approximated curve.

ギャップおよび永久磁石の磁気抵抗は，透磁率と要素寸 法で決まる線形の磁気抵抗であり, 比透磁率 $\mu_{s}$, 真空の透 磁率 $\mu_{0}$ を用いて, 次式で与えられる.

$$
R=\frac{l}{\mu_{s} \mu_{0} S}
$$

次いで, 永久磁石の起磁力 $F_{c}$ は, 保磁力 $H_{c}$ と磁石長 $l_{m}$ を用いて, 以下の式で与えられる。

$$
F_{c}=H_{c} l_{m}
$$

ただし, 本 IPM モータにおいては, Fig. 3 の “PM or Iron” 層のように磁石と鉄が混在するため, 回転子位置角 $\theta$ によ り起磁力が変化する。

Fig. 5 に, 回転子位置角に対寸る磁石起磁力の空間分布 を示す. 鉄心の領域である 45 度付近では磁石起磁力がゼロ になっていることがわかる，本稿では，この起磁力の空間 分布を次の関数で与える.

$$
\begin{aligned}
f_{c}(\theta) & =\frac{F_{c}}{\pi}\left[\tan ^{-1}\{500 \sin (4 \theta+5)\}\right. \\
& \left.+\tan ^{-1}\{500 \sin (4 \theta-5)\}\right]
\end{aligned}
$$

また，”PM or Iron”層の磁気抵抗 $R_{p g}(\theta)$ についても，回 転子位置角 $\theta$ の関数で表され，要素が鉄心の領域にあると きは，(2)式の非線形磁気抵抗となり，磁石の領域にあると きは, (3)式の線形磁気抵抗に変化する.

以上のように, 永久磁石の起磁力 $f_{c}$ と回転子の磁気抵抗 $R_{p g}$ を, 回転子位置角 $\theta$ の関数とすることで, 回転子の回転 運動が模擬可能になる.

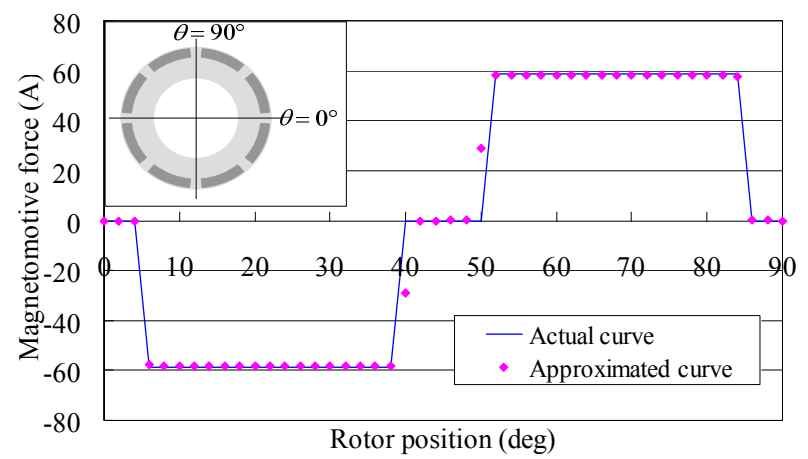

Fig. 5 Magnetomotive force of permanent magnet corresponding to rotor position. 


\section{2 RNA におけるトルクの計算手法}

RNA モデルにおける，トルクの計算手法について説明す

る. Fig. 6 に示寸ように, 円筒座標系に置かれた回転子が $z$ 軸に対して回転運動する場合, 回転子に作用するトルク $\tau$ は，次式で表される ${ }^{6}$.

$$
\tau=\int_{V}\left\{r(\boldsymbol{i} \times \boldsymbol{B})_{\theta}+\boldsymbol{B} \cdot \frac{\partial \boldsymbol{H}}{\partial \theta}\right\} d V
$$

$\boldsymbol{i}$ は電流ベクトル, $\boldsymbol{B}$ は磁束密度ベクトルであり, $\boldsymbol{H}$ は磁界 ベクトルである.

(6)式の体積分を面積分に書き直して変形すると, 次式が 得られる6).

$$
\begin{aligned}
\tau & =\int_{V}\left\{r(\boldsymbol{i} \times \boldsymbol{B})_{\theta}+\boldsymbol{B} \cdot \frac{\partial \boldsymbol{H}}{\partial \theta}\right\} d V \\
& =\int_{V}\left\{\frac{1}{r} \frac{\partial\left(r^{2} H_{\theta} B_{r}\right)}{\partial r}+\frac{1}{r} \frac{\partial\left(r H_{\theta} B_{\theta}\right)}{\partial \theta}+\frac{\partial\left(r H_{\theta} B_{z}\right)}{\partial z}\right\} d V \\
& =\int_{V} \operatorname{div}\left(r H_{\theta} \boldsymbol{B}\right) d V \\
& =\int_{S} r H_{\theta} \boldsymbol{B} \cdot \boldsymbol{n} d S
\end{aligned}
$$

従って，(7)式を Fig. 7 の RNA モデルに対応させて離散化 すると，トルクは以下のように求まる.

$$
\begin{aligned}
\tau & \approx \sum_{j=1}^{n_{\theta}} r H_{\theta j} B_{r j} \Delta S \\
& =\sum_{j=1}^{n_{\theta}} r \frac{F_{\theta j}}{2 \pi r / n_{\theta}} \frac{\phi_{r j}}{2 \pi r / n_{\theta} L} L r \Delta \theta
\end{aligned}
$$

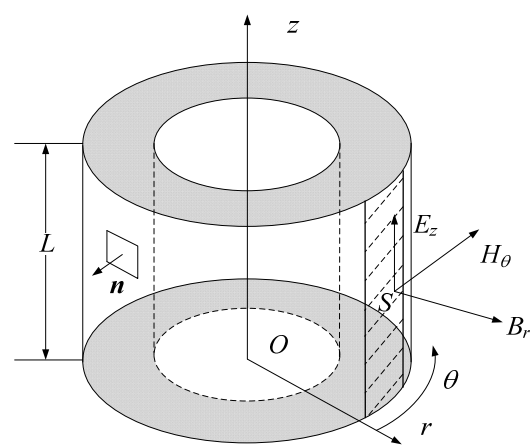

Fig. 6 Rotor in cylindrical coordinate system.

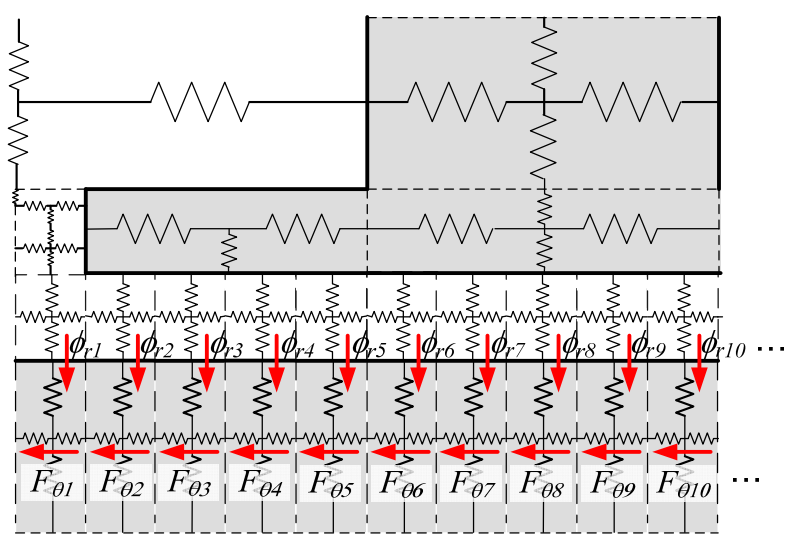

Fig. 7 MMFs and fluxes at each element in RNA model.

$$
\begin{aligned}
& =\frac{n_{\theta}^{2}}{4 \pi^{2}} \sum_{j=1}^{n_{\theta}} F_{\theta j} \phi_{r j} \Delta \theta \\
& =\frac{n_{\theta}^{2}}{4 \pi^{2}}\left[F_{\theta 1} \phi_{r 1} \frac{2 \pi}{n_{\theta}}+F_{\theta 2} \phi_{r 2} \frac{2 \pi}{n_{\theta}}+\cdots+F_{\theta n_{\theta}} \phi_{r n_{\theta}} \frac{2 \pi}{n_{\theta}}\right] \\
& =\frac{n_{\theta}}{2 \pi}\left\{F_{\theta 1} \phi_{r 1}+F_{\theta 2} \phi_{r 2}+\cdots+F_{\theta n_{\theta}} \phi_{r n_{\theta}}\right\}
\end{aligned}
$$

(8)式中の $F_{\theta j}$ および $\phi_{r j}$ は，Fig. 6 の RNA モデルにおけ る回転子表面の $j$ 番目の要素の, 周方向の起磁力および径 方向の磁束である. すなわち, RNA モデルにおいて回転子 に発生するトルクは, 回転子表面の要素の周方向の起磁力 と, 径方向の磁束の積を全ての要素について計算し, これ らの総和として与えられる.

\section{3. 特性算定結果}

\section{1. 基礎特性の算定結果}

Fig. 8 および Fig. 9 に, 無負荷で回転数が $3000 \mathrm{rpm} の$ 場合の固定子極の磁束と誘起電圧波形を示す。また, Fig. 10 に無負荷誘起電圧特性を示寸，比較のため，FEM によ る算定結果も併せて示寸，これらの図を見ると，両手法に よる算定結果はほぼ一致しており，導出した RNA モデル の妥当性が了解される.また従来のモデル5では, 誘起電圧 波形にスパイク状のノイズが重畳寸る問題があったが，本 稿で提案する新しいモデルには，ノイズがまったく認めら れないことが了解される。

Fig. 11 に, $d$ 軸電流を $0 \mathrm{~A}$ とした場合の電流対卜ルク特 性の算定結果を示寸，同図を見ると，トルク特性について も両者は良好に一致していることがわかる.

Table 1 に, RNA と FEM の計算時間の比較を示す. RNA を用いることで，計算時間は約 $1 / 6$ に短縮されることが了 解される。

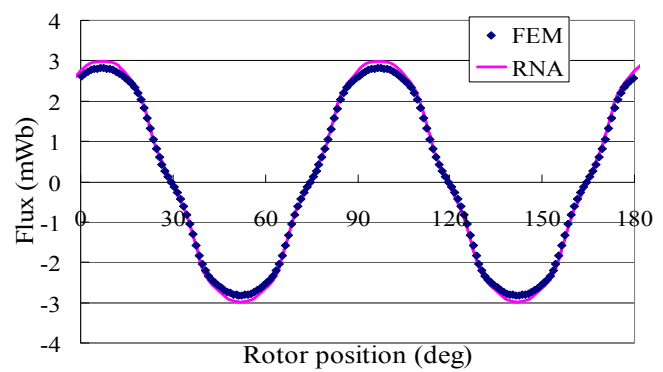

Fig. 8 Flux waveforms calculated with RNA and FEM.

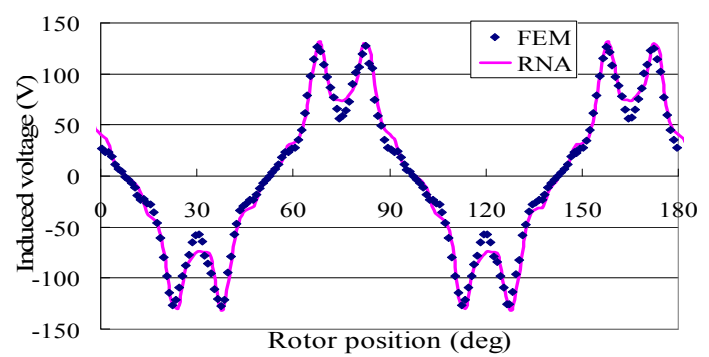

Fig. 9 No-load induced voltage waveforms calculated with RNA and FEM. 


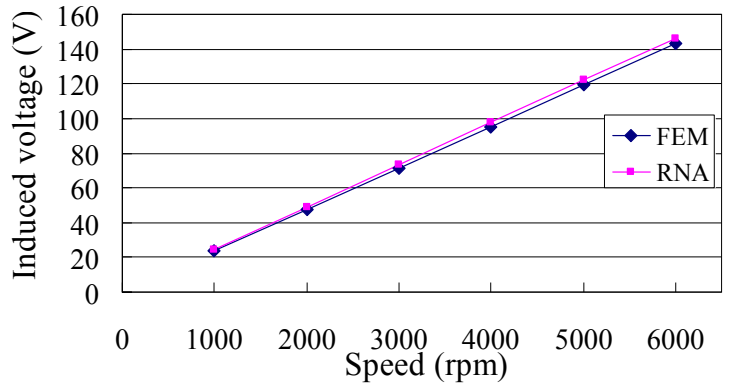

Fig. 10 No-load induced voltage characteristics calculated with RNA and FEM.

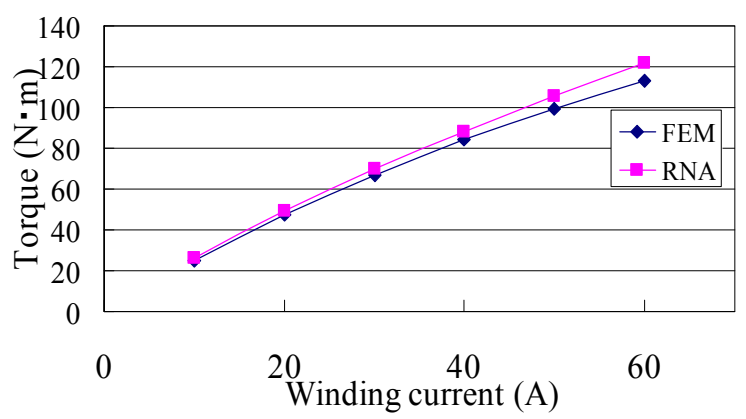

Fig. 11 Torque characteristics calculated with RNA and FEM.

Table 1 Comparison of calculation times.

\begin{tabular}{|c|c|c|}
\hline & RNA & FEM \\
\hline Number of elements & 219 & 28,769 \\
\hline Calculation time (avg. value) & 11 minutes & 65 minutes \\
\hline
\end{tabular}

\section{2. 鉄損特性の算定結果}

本節では, RNA による鉄損の算定結果について述べる. 鉄損の算定には, 以下のスタインメッツの実験式を用いた.

$$
W_{i}=A_{h} B_{m}{ }^{2} f+A_{e} B_{m}{ }^{2} f^{2}
$$

ここで, $A_{h}$ および $A_{e}$ はそれぞれヒステリシス損係数と渦電 流損係数であり, 材料の鉄損曲線から求めることができる.

まず Fig. 12 に示すように, IPM モータをいくつかのブ ロックに分け, 各ブロックにおける磁束密度波形を求める. 求めた磁束密度波形をフーリエ級数に展開し, 各周波数成 分ごとに(9)式を適用して鉄損を求め, 寸心゙ての周波数成分 の和として，各ブロックの鉄損を求める. 最後に, これら すべてのブロックの鉄損の総和を求めることで, 固定子と 回転子それぞれの鉄損を算出する.

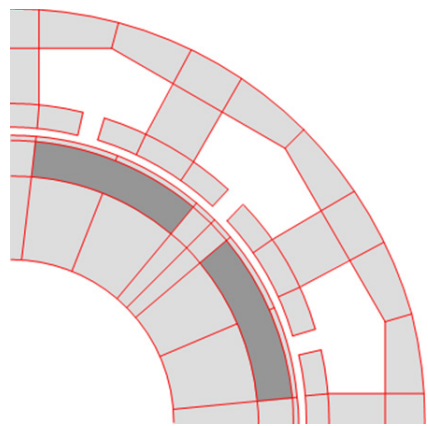

Fig. 12 Division of IPM motor for iron loss calculations.

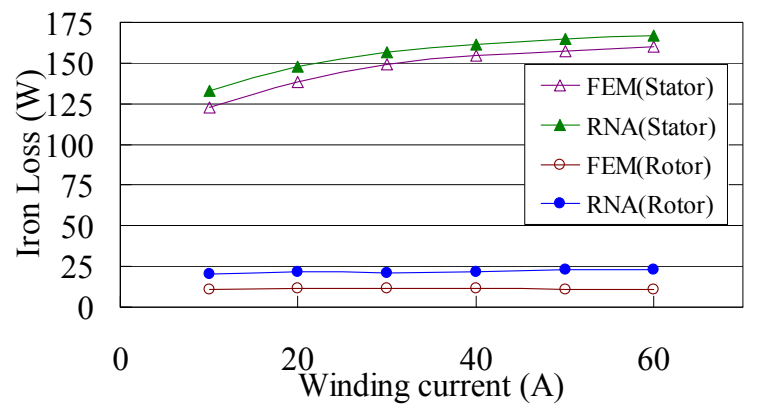

Fig. 13 Iron loss characteristics calculated with FEM and RNA.

Fig. 13 に，回転数 $3000 \mathrm{rpm}$ における固定子，回転子の 鉄損特性の算定結果を示す。この図を見ると，固定子，回 転子ともに, RNAの方が FEM よりも若干鉄損を大きく見 積もっていることがわかるが，定性的な傾向は良く一致し ている。なお，モータ全体の鉄損で比較すると，RNA FEM の誤差は約 10\%である.

\section{4. まとめ}

以上，リラクタンスネットワーク解析（RNA）に基づく IPM モータの特性算定について述べた.

まず，永久磁石の起磁力と回転子の磁気抵抗を回転子位 置角の関数で表すことで，回転子の回転運動を模擬する新 しい IPM モータの RNA モデルの導出方法について述心゙ た. 導出した RNA モデルを用いて諸特性の算定を行った ところ, 誘起電圧とトルクについては, FEM と波形レベル で一致することが明らかになった。 また，従来のモデルで 問題となった誘起電圧波形に重畳するスパイクノイズにつ いても，新しいモデルではまったく認められないことが明 らかになった。

鉄損特性に関しては，モータ全体の鉄損で比較すると 10\%ほどの差異が認められるが, RNAの分割数の少なさや 計算時間の短さを考えると，実用上，十分有用であると考 えられる. 今後は, 制御系との連成解析について検討を行 う予定である.

謝辞 本研究の一部は $\mathrm{NEDO} 「 \mathrm{Nd}-\mathrm{Fe}-\mathrm{B}$ 系磁石を代替する 新規永久磁石の研究」の助成を受け行った.

\section{References}

1) K. Nakamura and O. Ichinokura: J. Magn. Soc. Jpn., 28, 1089 (2004) (in Japanese).

2) K. Nakamura and O. Ichinokura: T. IEE Japan, 126-A, 150 (2006) (in Japanese).

3) T. Miyashita, K. Nakamura, and O. Ichinokura: J. Magn. Soc. Jpn., 31, 127 (2007) (in Japanese).

4) S. Fujio, K. Nakamura, and O. Ichinokura: J. Magn. Soc. Jpn., 30, 55 (2006) (in Japanese).

5) T. Hasegawa, H. Goto, K. Nakamura, and O. Ichinokura: J. Magn. Soc. Jpn., 33, 311 (2009) (in Japanese).

6) T. Kenjo and S. Nagamori : Shin Brushless Motor System Sekkei no Jissai (in Japanese), p. 149 (Sougou Denshi Shuppan, Tokyo, 2002).

2010年10月18日受理，2011年3月24日採録 